\title{
NOTES.
}

NOTE ON THE MESARCH STRUCTURE OF CERTAIN VASCULAR BUNDLES IN THE COTYLEDONS OF SOIME SCITAMINEAE.-The presence of bundles possessing a distinctly mesarch structure was first observed in this Order by Miss Sargant, in transverse sections of the sucking cotyledon of Brachychilum Horsfieldii, and the occurrence of short, broad, spirally-thickened tracheides situated centripetally to the protoxylem was at once confirmed by longitudinal sections of the seed and enclosed cotyledon.

The question arose as to whether this was a primitive character, or whether the presence of this centripetal xylem could be otherwise accounted for. The fact that the bundle was exarch in structure before it entered the cotyledon, then became mesarch for a space, but again became exarch towards the tip of that organ, seemed to indicate that this variation in structure might be due to some local adaptation.

Besides Brachychilum, the cotyledons of the Scitaminaceous seedlings, Alpinia calcarata, Roscoea purpurea, and Elettaria Cardamomum, were examined; those of Alpinia and Roscoea were found to resemble that of Brachychilum closely, not only in the presence of an apparently mesarch bundle, but in other features. In Elettaria, however, no such mesarch structure was found.

In the three former species the haustorial part of the cotyledon is provided with two vascular bundles; one of these passes into it directly from the stele, the other travels through the cotyledonary sheath first. Definite mesarch structure is only present in that which comes direct from the stele, but the relations of the constituent bundles of the two strands within the sucking cotyledon can be more easily traced in the other, and thus an explanation of the mesarch appearance of its companion arrived at.

When this trace is on the point of leaving the cortex and entering the cotyledonary sheath, it is joined by two small lateral bundles which form part of a cortical anastomosing system connecting the traces of all the leaves together. Sometimes these two small bundles fuse and join the main strand as one bundle, sometimes there is a short connecting branch between them, but in either case we have as a result a small bundle running close past the protoxylem of the main strand. Thus in Fig. 4 the smaller bundle, B, is formed by the union of the two laterals which have taken the courses indicated by the dotted lines, and it will be seen that one has passed very close to the protoxylem of the main cotyledonary strand, $\mathrm{c}_{2}$.

In the second cotyledonary strand which passes direct from the stele to the sucking cotyledon, this crossing of the paths of the three constituent bundles takes place while the two small cortical bundles are associated with the main trace, and

[Annals of Botany, Vol. XXIV. No. XCIV. April, 19ro.] 
the result is the apparent mesarchy of the whole strand. In Fig. I the three bundles are quite distinct, the two small laterals lying one on each side of the main strand. At this point the bundles have just left the hypocotyl. As they pass together up the cotyledon, the xylem from the lateral bundles spreads round the protoxylem of the main bundle, until the whole has a mesarch structure as shown in Fig. 2. In Fig. 3 the whole mass of centripetal wood has moved to one side; its position now may be
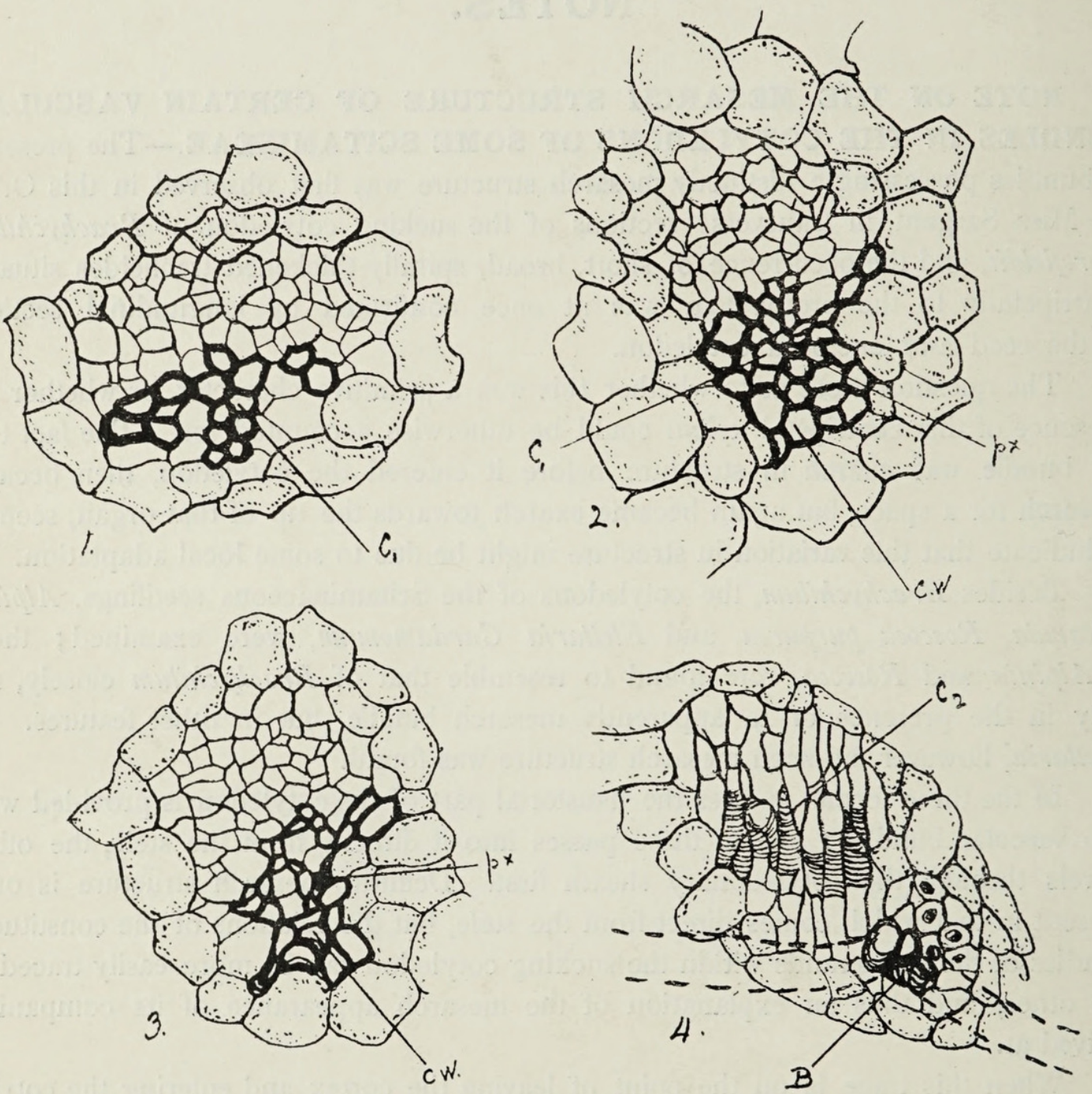

Fig. I. Roscoea purpurea. Triple strand entering the cotyledon. $\mathrm{C}_{1}=$ cotyledonary trace.

Fig. 2. Brachychilum Horsfieldii. Vascular strand showing mesarch structure. $p x=$ protoxylem ; c. $w_{0}=$ centripetal wood.

Fig. 3. Roscoea purpurea. Strand becoming exarch again with centripetal wood moving to one side.

Fig. 4. Fused cortical bundles, B, about to join second cotyledonary trace, $\mathrm{C}_{2}$.

compared with that of the fused laterals in Fig. 4. Finally in the upper part of the cotyledon the whole strand becomes exarch again.

Figs. 1, 3, and 4 are all taken from sections of seedlings of Roscoea purpurea, but in Fig. 2, a section cut from a seedling of Brachychilum has been substituted for the parallel case in Roscoea, as the mesarch structure was first observed in this set of sections and is very striking. In a neighbouring section a small amount of phloemlike tissue is to be observed accompanying the centripetal wood, and this is also the 
case in one of the Roscoea seedlings examined. It is, therefore, evident that the presence of centripetal wood in one vascular strand of the cotyledons of Brachychilum, Roscoea, and Alpinia, is due to the fusing of two small cortical bundles after they have become closely associated with the main strand, but before they are wholly merged in it.

It must be added that there is a tendency for large single tracheides to occasionally make their appearance on the side of the protoxylem remote from the metaxylem throughout the whole course of both bundles, but this is to be observed in the cotyledons of many monocotyledonous families. In Anemarrhena isolated tracheides occur scattered between the two bundles, and in Erythronium grandiflorum, where there are several laterals, their appearance usually precedes the fusion of two of these ; in Iris the single strand of fused bundles ends in a brush of these spirally thickened elements, while in Maianthemum a group of three tracheides was observed in the ground tissue quite apart from any vascular bundle.

In an organ whose most important function is the rapid passage of food substances to the growing plant, the occurrence of such elements is likely to-be an adaptive feature rather than a primitive one, and their frequent but by no means constant association with the bundles in a centripetal position does not necessarily indicate their vestigial nature.

Summary. The well-marked mesarch structure of one of the cotyledonary strands in the lower part of the sucking cotyledon of certain Scitamineae is evidently due to the relative movements of the constituent bundles after they have become associated together in a single strand, and is therefore of no phylogenetic importance.

E. M. BERRIDGE.

\section{PRELIMINARY NOTE ON APOGAMY IN PTERIS DROOGMANTIANA.}

-A cytological investigation of the prothallus of this Fern has revealed features of much interest. In the young prothallus, cells each containing two nuclei are common: it appears certain that in this form neither of the paired nuclei has migrated from an adjacent cell, as in every case a nucleus is present in each of the surrounding cells. Our available evidence indicates that the pair of nuclei are formed by the division of the nucleus of an ordinary cell, no cell-wall being laid down between the daughternuclei. After division has taken place the two daughter-nuclei remain for some time unfused, but, in most if not all cases, fusion eventually takes place. Stages in the fusion have been observed, and the resultant nuclei are very large and at first often lobed.

We are indebted to Mr. Boodle for kindly supplying us with material for examination.

E. L. STEPHENS.

M. G. SYKES. 


\section{$2 \mathrm{BHL}$ Biodiversity Heritage Library}

Berridge, Emily Mary. 1910. "Note on the mesarch structure of certain vascular bundles in the cotyledons of some Scitamineae." Annals of botany 24, 485-487. https://doi.org/10.1093/oxfordjournals.aob.a089280.

View This Item Online: https://www.biodiversitylibrary.org/item/262605

DOI: https://doi.org/10.1093/oxfordjournals.aob.a089280

Permalink: https://www.biodiversitylibrary.org/partpdf/319788

\section{Holding Institution}

New York Botanical Garden, LuEsther T. Mertz Library

\section{Sponsored by}

BHL-SIL-FEDLINK

\section{Copyright \& Reuse}

Copyright Status: Public domain. The BHL considers that this work is no longer under copyright protection.

This document was created from content at the Biodiversity Heritage Library, the world's largest open access digital library for biodiversity literature and archives. Visit BHL at https://www.biodiversitylibrary.org. 